ANDRZEJ CZYŻEWSKI, ANNA MATUSZCZAK

\title{
Integration of spendings on the agricultural sector in the national budget and the budgets of voivodes in Poland in the long term (2000-2013)
}

Prof. Andrzej Czyżewski, Full Professor Poznan University of Economics Head of the Department of Macro and Agricultural Economics

Ph.D. Anna Matuszczak, Assistant Professor Poznan University of Economics Department of Macro and Agricultural Economics

\section{Introduction}

The purpose of this article is to identify the areas of integration spendings on the agricultural sector in the national budget and the budgets of voivodes in the years 20002013, with particular emphasis on the first full perspective of the EU budget (2007-2013), in which Poland participated. Expenses are analyzed both from national and EU budget flowing to the agricultural sector in Poland, distributed at the central and provincial level. Then integration expenses will be shown on the agricultural sector in the central agricultural budgets and the budgets of voivodes with regard to the financing of projects involving EU funds, which will help to determine the complementarity and substitutability of taken action. The source material on which are based the analysis is carried out projects and the implementation of the budget set for each year.

2. National and EU spendings on the agricultural sector in the Polish budget

Central expenditures on the agricultural sector are budgetary resources directed to 
the sector that remain at the disposal of the Minister of Agriculture and Rural Development. The analysed time period is divided into three sub-periods: first determined by integration with the EU (2000-2003), the second covers the years after accession (2004-2009), and the third, when Bank Gospodarstwa Krajowego (BGK), took over the operation of the established budget of resources (since 2010). Thus, since 2003 spendings in the agricultural budget inspired pessimism. It was hard to recognise that agriculture was the preferred policy of the government - the share of spendings on the agricultural sector in budgetary expenditures showed stagnation oscillating at around 2.2\% of the total expenditures and registering dangerous drops, as in 2002, to the level of less than $2 \%$ (see Figure 1). One can also consider that the situation of the agricultural sector deteriorated since the beginning of the transformation of Polish economy and negligence taking place over the years testify to the progressive marginalization of the problems of agriculture, rural areas and agricultural markets in subsequent state budgets. By 2003, the economic situation of farms in comparison to nonagricultural environment had not improved, on the contrary, civilization gap for most of them grew and degradation deepened. Expenditures projected in the budget acts were not able to alleviate the fundamental problems of agriculture and Polish rural areas, such as disparity of income, education or the condition of social infrastructure, despite the fact that together with expenditures on the social sphere - the Agricultural Social Insurance Fund (Polish: Kasa Rolniczego Ubezpieczenia Społecznego - KRUS), their share in the budget amounted on average to $10.8 \%$ [Czyżewski, Matuszczak 2011].

Since 2003, agriculture has clearly „bounced back”, which was reflected in sustained and real growth in budget spendings on the agricultural sector and also change in the existing relationships and trends. The average share of spendings on agriculture, rural development and agricultural markets along with KRUS did not actually change (marginal decrease by 0.2 percentage point), but the relationship of development spendings to social spendings has changed. For the first time, there has been a chance to directly improve the income of farmers and reproduction processes on their farms due to more than doubled spendings (average in years 2003-2009 4.8\%) on agriculture, rural development and agricultural markets from the national budget. Breaking the recessionary situation in Poland was achieved by improving the macroeconomic conditions of economy, in which we have seen a chance to halt the growing degradation of Polish agriculture and rural areas. Increased budgetary outlays were obviously not able to immediately solve the basic problems of the agricultural sector in Poland, as this required many years of consistent agricultural policy. 


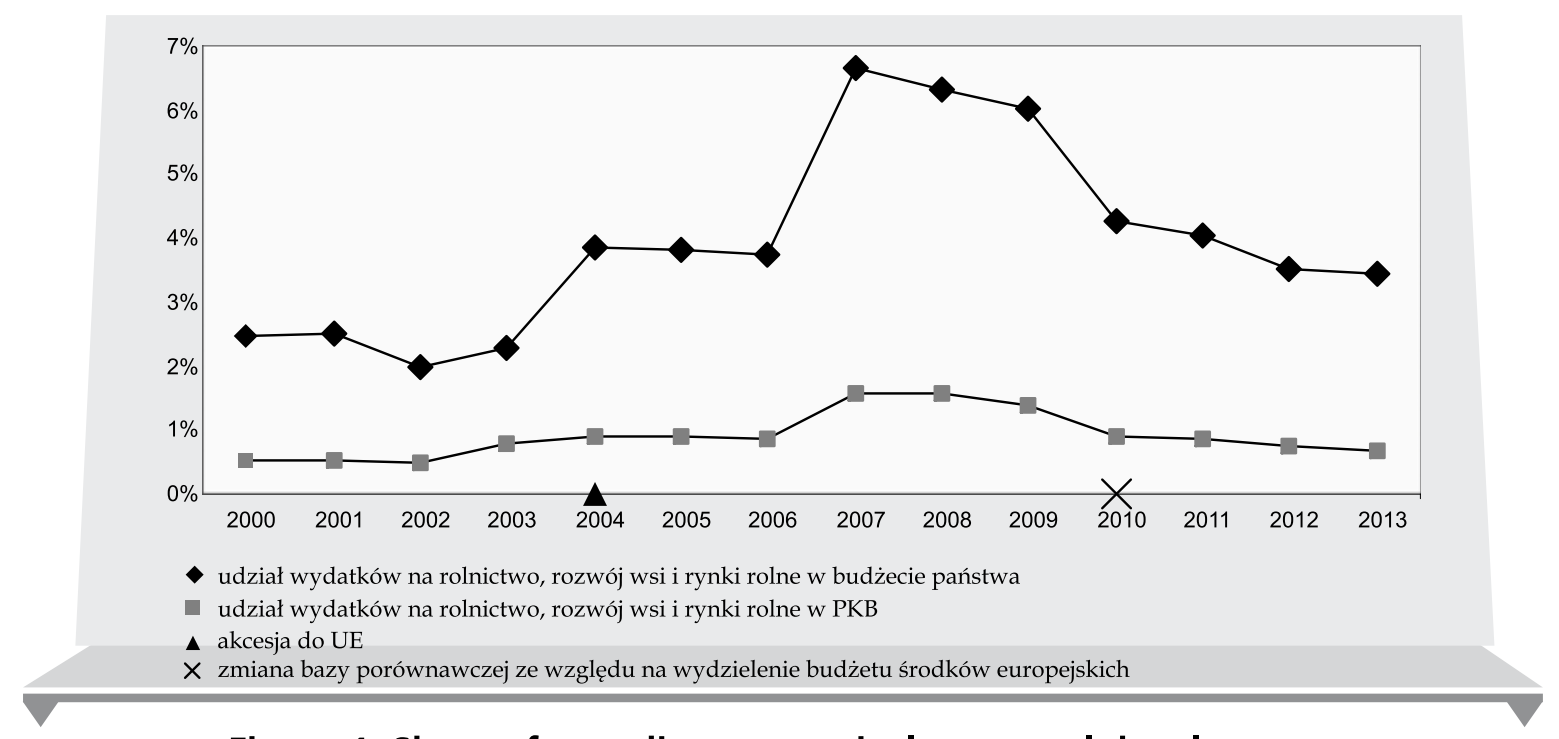

Figure 1. Share of spendings on agriculture, rural development and agricultural markets in the state budgets and GDP in $2000-2013$ (\%)

* comparisons to previous years relate to the provisions of the budget acts

** spendings on the agricultural sector is spendings on agriculture, rural development and agricultural markets along with the budgets of voivodes and specific provisions, excluding funds for co-financing and pre-financing of the EU objectives and programmes as well as KRUS

Source: opracowanie własne na podstawie corocznych opinii budżetu rolnego dla lat 2000-2013 sporządzonych przez A. Czyżewskiego w formie ekspertyz dla Kancelarii Senatu RP bazujących na analizie projektów i wykonania ustaw budżetowych za odpowiednie lata

After 2009, the situation has changed, but only from an accounting point of view - there has been a change in the functioning of the agricultural budget, as the Bank Gospodarstwa Krajowego (BGK), took over the operation of the European funds budget created on 1.01.2010, and thus became a central institution handling income and expenditures resulting in settlements with the EU. This has resulted in the separation of these funds from income, spendings and the deficit of the state budget. Thus, only in the accounting terms, there has been a drop in the share of spendings on agriculture, rural development and agricultural markets after 2010 (see table 1), because the actual expenditures on these headings along with the budgets of voivodes and the specific provisions in 2010 were actually higher by $28.84 \%$ as compared to the previous year.

In 2011-2013, these funds were reduced in real terms respectively by $7.55 \%$, $12.9 \%$ and $14,8 \%$ as compared to the previous year. However, these funds 
increased by expenditures on KRUS give in 2013 the share $8.39 \%$ - on a similar level to 2012, where he was respectively $8.34 \%$ and lower than in previous years, which amounted to $9.1 \%$ in 2011 and $9.83 \%$ a year earlier.

Considering the support of the national agricultural sector can not be overlooked flow of funds from the EU budget, which is the main beneficiary. Starting in 2006, the year preceding the current financial perspective 2007$2013-43.3 \%$ of the EU funds received for the sector, and in the following years, respectively, in 2007 - 43.28\%, in 2008 - 41.49\%; and in 2009 - 48.49\%. After 2010, this share gradually began to decline, including due to the completion of the established tasks to the level of 35.9\%, and respectively in $2011-31.9 \%$, in 2012 - $29.8 \%$, in $2013-28.8 \%$. No doubt this had a real impact on the development process and the accumulation of domestic farms.

It should also be noted that for many years government has consistently and increasingly involves the development of domestic agriculture, rural areas and rural areas with funds from the EU. The share of EU funds in the total expenditures of the national budget to agriculture, rural development and agricultural markets with ASIF steadily increased during this period. In 2004 it amounted to only $25.1 \%$, in 2005 already $41 \%$, in $2006-46.5 \%$, with the exception of 2007 , when it fell to $39 \%$, which was repeated in 2008 - 35\% to again rapidly increasing since 2009 - 49.9\%, in 2010 - 71.26\%, in 2011 - 79.93\%, in $2012-77.53 \%$, and in 2013, up $89.09 \%$. These figures show a growing trend to increase the share of EU aid budget spendings on the agricultural sector in Poland, but show that in 2013, this trend will be maintained and the share of EU agricultural budget in the national Polish (with ASIF) will increase by 11, 56 percentage points.

\subsection{Budgets of voivodes}

The concept of voivodeship spendings on the agricultural sector is understood as units and activities financed from the budgets of voivodes. Their general division applies to current expenditures, investment and co-financing of projects from the EU funds ${ }^{1}$. More detailed expenditures are those on institutions such as: voivodeship agricultural advisory centres, voivodeship inspectorates for agricultural and food quality inspection, voivodeship inspectorates for plant health and seed inspection, voivodeship and poviat veterinary inspectorates, the National Fisheries Service. As for the tasks to be undertaken within the budgets of voivodes, we may mention: geodetic and management work for agriculture,

1 This item is in the budgets of voivodes since 2004, since the Polish integration with the EU. 
water management, water law companies, plant protection, the fight against infectious diseases and monitoring chemical and biological residues in animal tissues and products of animal origin, removal of natural disasters.

Analysing the relationship of agricultural spendings from budgets of voivodes and agricultural expenditures from the central budget, we can see it has been deteriorating. In the pre-accession period, voivodes had similar nominal amounts each year (which means that in real terms they were getting lower), and after the integration we can observe that the average annual increase in agricultural expenditures was $11 \%$. However, this was not enough, with central expenditures on the sector growing faster, to maintain their share in voivodeship spendings at $1 / 4$ - as indicated in Table 1 , it decreased to $1 / 5$. This may indicate a growing importance of objectives in the central budget under conditions of the CAP implementation. This should be considered to be a general trend in the EU. This can be observed when under the EU agricultural policy we have to do with its formal centralization (Directorate-General for Agriculture) and when, at the same time, there is a clear pressure to decentralize (Directorate-General for Regional Policy) ${ }^{2}$.

Table 1. Relationship of expenditures in voivodeship budgets in agriculture and hunting section to central expenditures* on the agricultural sector in 2000-2013

\begin{tabular}{|c|c|c|c|c|c|c|}
\hline \multirow[b]{2}{*}{ Description } & \multicolumn{6}{|c|}{ Before accession to the UE } \\
\hline & 2000 & 2001 & 20 & & 2003 & average \\
\hline \multirow[t]{3}{*}{$\begin{array}{l}\text { Relationship of expenditures in voivodeship } \\
\text { budgets in agriculture and hunting section to } \\
\text { central expenditures* on the agricultural sector }\end{array}$} & 0,247 & 0,213 & \multicolumn{2}{|c|}{0,248} & 0,211 & 0,23 \\
\hline & \multicolumn{6}{|c|}{ After accession to the UE } \\
\hline & 2004 & 2005 & & & 2007 & 2008 \\
\hline \multirow{3}{*}{$\begin{array}{l}\text { Relationship of expenditures in voivodeship } \\
\text { budgets in agriculture and hunting section to } \\
\text { central expenditures* on the agricultural sector }\end{array}$} & 0,251 & 0,276 & \multicolumn{2}{|c|}{0,451} & 0,113 & 0,046 \\
\hline & 2009 & 2010 & 2011 & 2012 & 2013 & average \\
\hline & 0,11 & 0,156 & 0,17 & 0,198 & 0,205 & 0,197 \\
\hline
\end{tabular}

*Relationship of part 85 to the sum of 32,33 and 35 in budget acts

Source: as in Figure 1

2 More about these dillemmas in articles: Trouve A., Berriet-Sollec M. (2010), Elias A. (2008), Keating M. (2008). 
By studying the structure of spendings on agriculture in the budgets of voivodes, we can see that until the time of Polish integration with the EU, spendings volume on objectives envisaged for implementation in the budgets of voivodeships was characterized by stagnation. One may even recognise that although nominally the funds did not change, in real terms they were reduced.

Table 2. Structure and dynamics of expenditures in budgets of voivodes in agriculture and hunting section in $2000-2013$

\begin{tabular}{|c|c|c|c|c|c|c|}
\hline \multirow[b]{2}{*}{ Description } & \multicolumn{6}{|c|}{ Before accession to the UE } \\
\hline & 2000 & 2001 & 2002 & & 2003 & average \\
\hline $\begin{array}{l}\text { Total expenditures (PLN thousand), } \\
\text { including: }\end{array}$ & 679680 & 662002 & 623569 & \multicolumn{2}{|r|}{632752} & 649500 \\
\hline Dynamics & - & 0,97 & 0,94 & & 1,01 & 0,98 \\
\hline Structure, including: current expenditures & 0,84 & 0,85 & 0,84 & & 0,88 & 0,85 \\
\hline \multirow[t]{3}{*}{ capital expenditures } & 0,16 & 0,15 & 0,16 & \multicolumn{2}{|r|}{0,12} & 0,15 \\
\hline & \multicolumn{6}{|c|}{ After accession to the UE } \\
\hline & 2004 & 2005 & 2006 & & 2007 & 2008 \\
\hline $\begin{array}{l}\text { Total expenditures (in PLN thousand), } \\
\text { including: }\end{array}$ & 668600 & 658212 & 900013 & & 1152259 & 789741 \\
\hline Dynamics & 1,06 & 0,98 & \multicolumn{2}{|c|}{1,37} & 1,28 & 0,69 \\
\hline Structure, including: current expenditures & 0,86 & 0,91 & 0,78 & & 0,57 & 0,88 \\
\hline capital expenditures & 0,14 & 0,09 & 0,22 & & 0,03 & 0,06 \\
\hline \multirow[t]{2}{*}{ co-financing of projects from the EU funds } & - & - & - & \multicolumn{2}{|r|}{0,40} & 0,06 \\
\hline & 2009 & 2010 & 2011 & 2012 & 2013 & average \\
\hline $\begin{array}{l}\text { Total expenditures (PLN thousand), } \\
\text { including: }\end{array}$ & 1289491 & 909397 & 1120250 & 1159052 & 21264585 & 991160 \\
\hline Dynamics & 1,63 & 0,71 & 1,23 & 1,03 & 1,09 & 1,11 \\
\hline Structure, including: current expenditures & 0,62 & 0,87 & 0,71 & 0,69 & 0,64 & 0,72 \\
\hline capital expenditures & 0,02 & 0,03 & 0,10 & 0,10 & 0,11 & 0,08 \\
\hline co-financing of projects from the EU funds & 0,36 & 0,10 & 0,19 & 0,21 & 0,25 & 0,2 \\
\hline
\end{tabular}

Source: as in Figure 1 
The situation was reversed after 2005, when from year to year a relatively high increase was noted. For eight years of Polish membership in the EU voivodeship budget expenditures almost doubled.

Considering the dynamics of the expenditures for the individual headings in the budgets of voivodes in agriculture and hunting section, it is noticeable that the most stable expenditures over the period in question are the expenditures on budgetary units and entities. Heading, which needs to be distinguished due to the highest, doubled spendings growth in the post-accession period, as compared to the time prior to the integration, is the financing of water law companies and management. Especially the latter has been significantly supported by the investments covered by both national resources and especially by the relatively fast-growing EU funds.

\section{Substitutability and complementarity of spendings on the agricultural sector in the national budget and the budgets of voivodes}

In search of substitutability and complementarity of the expenditures on the agricultural sector in the national budget and the budgets of voivodes, indicate the following phenomena:

1. Interesting is the structure of expenditures in the budget of voivodes in agriculture and hunting section, in which until 2005 there was a relatively stable division into current expenditures (85\%) and relatively low capital expenditures (15\%). 2006 brought a radical change with increasing share of capital expenditures, and a year later EU funds were involved in the financing of voivodeship budget headings, which resulted in prominent increase in the share of investments. After the accession of Polish accession to the EU this relation changed in favor of the investment $(31 \%)$, mainly financed by the EU (of which more than two thirds came from the EU, see Figure 2). Therefore we can refer to a noticeable substitution of current expenditures with capital expenditures, as well as some complementarity of domestic investment spendings with the EU funds. Projects co-financed from the EU funds made it possible to implement a much greater number of projects in the field of geodetic and management works, as well as land reclamation for agriculture. One should also note that the EU budget takes over implementation of some of the headings, which greatly relieves the national budget. 


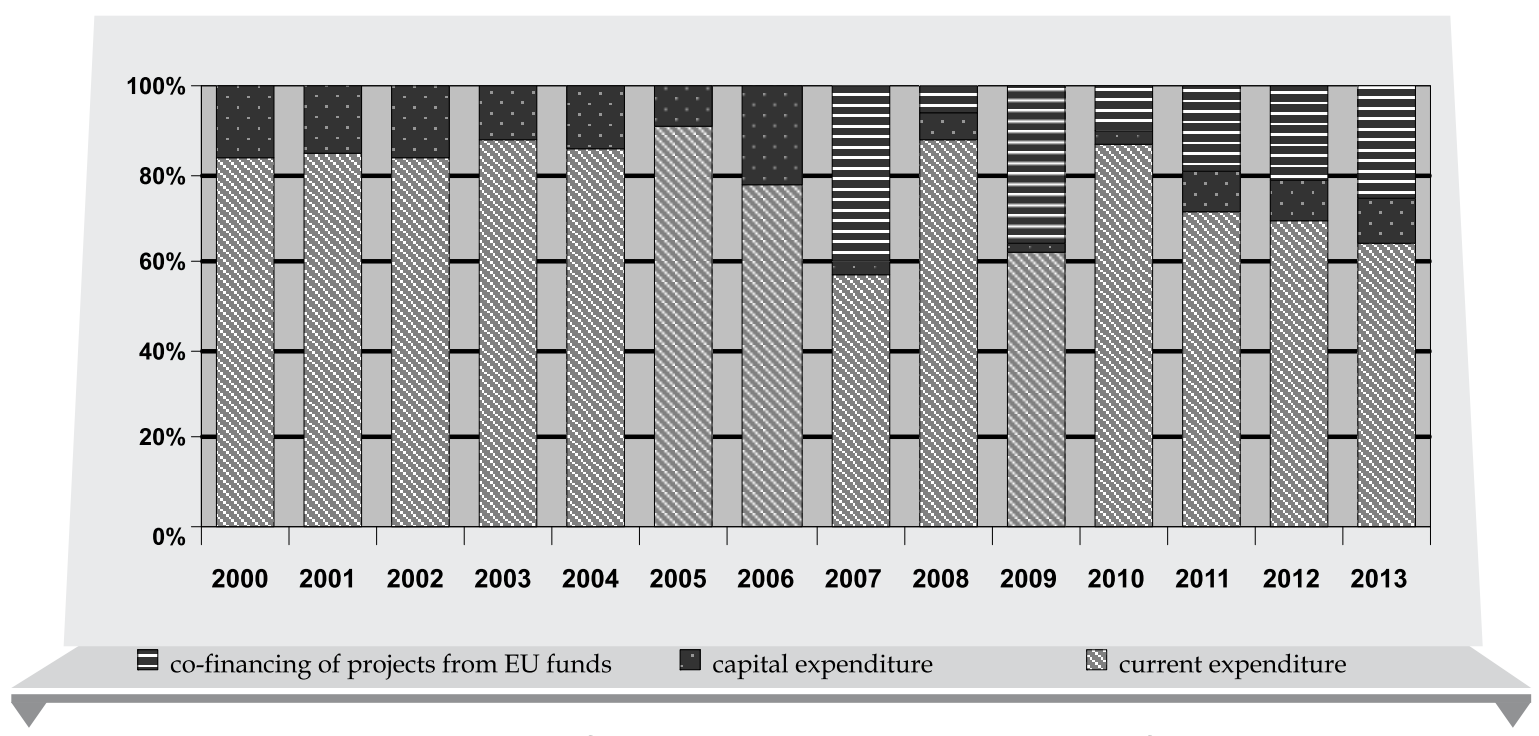

Figure 2. Structure of expenditures in the budgets of voivodes in agriculture and hunting section in $2000-2013$

Source: as in figure 1

2. With the implementation of the CAP, the number of headings is increasing, not only in the central budget, but also - although to a lesser extent - in the budgets of voivodes. We are talking primarily about the tasks carried out under the RDP (for voivodes, but carried out by the offices of the marshal, which include the consolidation of land and water resources management) and dealing with the consequences of natural disasters, as well as financing through EU projects.

3. An important position assuming the criterion of spendings budget on the agricultural sector, there are meliorations water. Expenditures concern both their maintenance, as well as new investments. We also observe an increasing share (from about $1 / 5$ to $1 / 4$ ), but mainly thanks to much fluctuating investments from the EU funds, which in a significant part substitute domestic investments in this area. It is also worth to mention the item associated with geodetic and management work for agriculture, for which the share of expenditures over the period (2004-2013) in stable and remains at about 5\% (Czyżewski, Matuszczak 2012).

\section{Conclusions}

These considerations are entitled to the following conclusions: 
1. Expenditures of the budget in the section on the agricultural sector for many years was a compromise between what is necessary and what is possible. At the same time we can not say that this sector of the economy was in any way preferred, which would increase its competitiveness against other branches. But it is reasonable to say that by 2003 expenditures remained at a stable but very low level, making it impossible to meet the established priorities of economic policy, assuming the restructuring of the agricultural sector. Thus, the union general expenses of the state budget expenditures on the agricultural sector was relatively small.

2. Since 2004, the situation has changed significantly, both quantitative and qualitative. Analysis of budgetary laws shows that thanks to the co-financing of EU funds and programs, as well as supplementary financing payment scheme (direct, including from the Rural Development Programme of the second pillar) by the national budget expenditures on the agricultural sector actually increased, stabilizing at close 2.5 times higher than in the preaccession period. In this situation, it can be spent for these integrated. At the same time it should be noted that the rank of the agricultural budget in the light of a national budget after the accession to the EU has increased in real terms.

3. Financial flows between the EU and Polish for the purpose of agriculture, rural development, agricultural and fisheries markets since the beginning of the integration of the Polish side effects bring the net. It should be noted that the total amount of funds transferred to Poland in the coming years the EU has been much higher than the contribution paid by Poland. From the above analysis shows that agriculture and rural areas in Poland are major net beneficiary Polish integration with the EU, and what's more benefices will be on the scale are increasing throughout the financial support of the EU Polish 2007-2013.

4. Llong-term trends in expenditures on the agricultural sector in the central budget and the budgets of voivodes to a relatively large extent correspond to the directions of the proposed amendments to the Common Agricultural Policy in 2014-2020, which is reflected, for instance, in the increasing importance of objectives in the central budget and the increasing number of headings in the budgets of voivodes. These expenditures (e.g. related to the regulation of water conditions) are often complementary to the EU funds flowing to the agricultural sector for investments, they are also often substituted by funds from the EU. 


\section{Summary}

Integration of spendings on the agricultural sector in the national budget and the budgets of voivodes in Poland in the long term (2000-2013)

The purpose of this article is to identify the areas of integration spendings on the agricultural sector in the national budget and the budgets of voivodes in the years 2000-2013, with an indication of the processes of their complementarity and substitutability. There was analyzed the expenditures of national and the EU budget flowing to the agricultural sector in Poland, showing their significant increase after the Polish integration with the EU. Was noticeable, however, that increasing spendings on the agricultural sector from the national budget could be „enforced” by increasing funding from the EU. This indicates the integrity understood as complementary to each other. Then shown the complementarity and substitutability spendings on the agricultural sector in the central agricultural budgets and the budgets of voivodes with regard to the financing of projects involving EU funds, noting ongoing trends.

Keywords: agriculture, the central budget, the budgets of vovodes, expenses, complementarity, substitutability.

\section{Streszczenie}

Integracja wydatków na sektor rolny $w$ budżecie centralnym i budżetach wojewodów w Polsce w długim okresie (2000-2013)

Celem artykułu było wskazanie na obszary integracji wydatków na sektor rolny w budżecie centralnym i w budżetach wojewodów w latach 2000-2013, ze wskazaniem na zachodzące procesy ich komplementarności i substytucyjności. Przeanalizowano wydatki z krajowego oraz unijnego budżetu płynące do sektora rolnego w Polsce, wykazując na ich istotne zwiększenie po integracji Polski z UE. Zauważalne było jednocześnie, że rosnące wydatki na sektor rolny z budżetu krajowego mogły być „wymuszane” przez rosnące środki z UE. Wskazuje to na ich integralność rozumianą jako komplementarność wobec siebie. Następnie ukazano komplementarności i substytucyjności wydatków na sektor rolny w centralnych budżetach rolnych i budżetach wojewodów 
z uwzględnieniem finansowania projektów z udziałem środków europejskich, zaznaczając utrwalające się tendencje.

\section{Słowa}

kluczowe: sektor rolny, budżet centralny, budżety wojewodów, wydatki, komplementarność, substytucyjność.

\section{References}

1. Czyżewski A., Matuszczak A. (2011), Krajowy i unijny budżet rolny dla Polski. Próba określenia proporcji, wspótzależności oraz efektów dla sektora rolnego, [w] B. Wieliczko (red.), Ocena projekcji budżetowych UE dotyczacych kolejnego okresu programowania w kontekście Wspólnej Polityki Rolnej, Program Wieloletni 2011-2014, IERiGŻ-PIB, Warszawa.

2. Czyżewski A., Matuszczak A. (2012), Wydatki na sektor rolny w Polsce $w$ budzecie centralnym $i$ budżetach wojewodów w latach 2000-2012 oraz możliwości ich przesunięć w kontekście przewidywanych zmian WPR 20142020, [w] B. Wieliczko (red.), Ocena projekcji budżetowych UE dotyczacych kolejnego okresu programowania w kontekście Wspólnej Polityki Rolnej, Program Wieloletni 2011-2014, IERiGŻ-PIB, Warszawa.

3. Coroczne opinie budżetu rolnego dla lat 2000-2013 sporządzone przez A. Czyżewskiego w formie ekspertyz dla Kancelarii Senatu RP bazujących na analizie projektów i wykonania ustaw budżetowych za poszczególne lata.

4. Trouve A., Berriet-Sollec M. (2010), Regionalization in European Agricultural Policy; institutional actualities, issue and prospects, „Regional Studies”, 44.8: 1005-101.

5. Elias A. (2008), Introduction: Whatever happened to the Europe of Regions? Revisiting the regional dimension of European politics, „Regional and Federal Studies" 18.5.

6. Keating M. (2008), A quarter century of Europe of the Regions, Regional and Federal Studies" 18.5. 